RECENZII

\title{
LA DAME À LA LICORNE
}

\section{Paul VASILESCU*}

Concis: Mondializarea și apartenența la blocul juridic european promiteau parcă mai multă ardoare pentru studiul comparat al dreptului. Nu s-a întâmplat acest fapt, cel puțin în ultimul deceniu, dar aceasta nu a împiedicat afirmarea unor cercetători pasionați de comparația juridică. În rândurile de mai jos trecem în revistă o lucrare aparte, importantă și demnă de a fi reținută. „Şapte dileme în teoria comparației” este o culegere de texte a drei Raluca BERCEA centrate pe fenomenul comparatist, pe categoriile acestuia și pe ambientul său de desfășurare. Înțelegerea dreptului ca fenomen cultural, dincolo de orizontul pozitivist, permite autorului să atace chestiuni dintre cele mai dificile - adevărul textual al dreptului, mecanismele comparatismului și metodologia acestuia, structura discursului comparatist ș.a. Invitația noastră la lectură e justificată de calitatea scriiturii şi de bogăția ideilor înfățișate.

Cuvinte cheie: adevăr juridic, drept comparat, interpretare, metode comparatiste, metadiscurs, metatext, realism juridic, sintaxă, textualism.

* Facultatea de drept a Universității Babeș-Bolyai din Cluj, paul.vasilescu@law.ubbcluj.ro. 


\title{
LA DAME À LA LICORNE
}

\begin{abstract}
Globalization and being a part of the European legal bloc promised more zeal for the Romanian comparative study of law. This has not happened in the last decade, but it has not prevented the assertion of researchers passionate about the legal comparison. We review a particular work, essential and worthy of being remembered. 'Şapte dileme în teoria comparației' (Seven dilemmas in the comparative theory) is a collection of texts by Ms Raluca BERCEA focused on the comparative phenomenon, its categories, and its environment. Understanding law as a cultural phenomenon beyond the positivist horizon allows the author to attack the most challenging issues - the textual truth of the law, the mechanisms of comparativism and its methodology, the structure of comparative discourse, etc. Our invitation to read is justified by the quality of the writing and the richness of the ideas presented.
\end{abstract}

Keywords: juridical truth, comparative law, interpretation, comparative methods, metadiscourse, metatextuality, legal realism, syntax, textualism.

\section{LA DAME À LA LICORNE}

Bref : Le droit comparé roumain ne connaît pas un essor important en dépit du droit applicable sur le sol roumain, et aussi à l'appartenance du système juridique interne à l'ordre du droit européen. Pour autant on ne peut parler d'une sècheresse profonde de la doctrine roumaine du droit comparé, car il y a aussi des travaux en la matière qui méritent toute notre attention, ainsi que le recueil Sept dilemmes de la théorie comparatiste, signé Raluca BERCEA. Tout en attaquant le droit comme phénomène culturel, l'auteur nous propose des essais assez bien ciblés sur des thèmes tels que les méthodes comparatistes, le discours juridique positif et ses outils métadiscursifs, le rapport existant entre la vérité du droit et celle des textes, la balance entre les divers subjectivismes analytiques etc. Le livre constitue un exemple textuel irréprochable méritant une lecture attentive quelle que soit la conviction intime du lecteur.

Mots-clés : vérité juridique, droit comparé, interprétation, méthodes comparatistes, métadiscours, métatexte, réalisme juridique, syntaxe, textualisme. 
Dreptul comparat nu este chiar preferatul autorilor, profesorilor ori a juriștilor români. Oarecum paradoxal, căci apartenența la un spațiu cultural închegat și cu origini comune decelabile ar fi trebuit să fie cel puțin un imbold pentru efortul comparatist. În plus, însuşi dreptul Uniunii Europene, precum și eforturile de codificare de genul celor petrecute în sânul comisiei Lando, toate ar fi constituit dacă nu un temei, măcar un pretext pentru a exploata pista comparatistă a dreptului. Evident, studii autohtone ${ }^{1}$ comparatiste, dar și traduceri ale unor opere esențiale ${ }^{2}$ nu ne lipsesc, dar parcă și acestea vin să sublinieze o lipsă, iar nu să umple un gol. Vidul are ecou în dedicare şi consecvență, în transformarea dreptului comparat în ceva mai mult decât în diletantism savant sau manipulare autohtonă. În fond, abia ultimul aspect ar fi cel de blamat, mai ales când vine de la nomothet și proptelele sale executive. Referința curentă la un alt drept - de fapt la o soluție legislativă străină - se face numai cu scopul de a justifica o anume opțiune normativă carpatină. „Şi în America există o lege aşa, deci, e firesc să o adoptăm și noi!” Oportunism și instrumentalizare normativă a unui text străin, care țin loc de explicație și justificare a necesității adoptării unei anume soluții legale locale. Dispensă de temei, trimitere doctă la o soluție juridică deja practicată aiurea. Iată rațiunea practică a dreptului comparat la noi, cel puțin în ochii făcătorului de legi și a suporterilor săi executivi (sau nu).

Raluca BERCEA stă cu spatele la acest peisaj. Nu se îndepărtează de el, pentru că nu a făcut parte din el, nu l-a frecventat și nici nu dă semne că ar

1 M. GuȚAn, Sisteme de drept comparate. Introducere în teoria generală a dreptului comparat, ed. Hamangiu, Bucureşti, 2014; I. LEȘ - Sisteme judiciare comparate, ed. All Beck, Bucureşti, 2002.

2 L.-J. Constantinesco, Tratat de drept comparat, vol. I-III, ed. All, Bucureşti, 1997-1998, 2001, traducere D. SCARLAT; P. LEgrand, Dreptul comparat, ed. Lumina lex, Bucureşti, 2001, traducere R. BERCEA. 
vrea să-i treacă hotarele. Raluca BERCEA se ocupă de drept comparat ca și cum numai acesta ar exista. Menirea sa este să ne dea o cheie, nu să ne explice soluțiile dreptului intern prin ruginitul „și la alții e cam tot aşa”. Dreptul comparat poate fi un lucru serios - la fel de serios ca omul care se ocupă de el; acum avem această probă. Dreptul comparat devine serios atunci când e surprins și dez-integrat în și din cultura sa eponimă. Se poate face drept comparat și fără juxtapuneri de două-patru articole din trei legi - una slovacă, una românească și alta peruviană. Serios înseamnă aici nu să încerci să compari texte de lege, ci să găsești temeiurile diferențelor manifestate în drept, să tratezi juridicul ca fenomen eminamente cultural, depăşind orice explicație preponderent pozitiv-tehnică pentru o viață de jure. Proba de care aminteam, serioasă şi pertinentă, se constituie în lucrarea la care facem mai jos trimitere.

Şapte dileme în teoria comparației este o carte ${ }^{3}$ recentă a dnei BERCEA care cuprinde eseuri despre cum să înțelegem provocările dreptului comparat, opul încheindu-se cu un text semnat de Pierre LEGRAND4, a cărui lignée o continuă în parte și autorul român. Substanța cărții ni se înfățișează printr-un montaj interogativ, nu neapărat retoric, care ar surprinde cele mai importante momente ale unui efort juridic comparativ. Se aduc în discuție și se prezintă variante interpretative despre raporturile dreptului comparat cu întinderea legislativă contemporană (mondializare și europenizare) a materiei, cu metodele de împrumut sau de inventat pentru a face comparații, cu jocul dinspre obiectiv către subiectiv pe care comparatistul e invitat să-l

3 R. BERCEA, Şapte dileme în teoria comparației, ed. C.H. Beck, București, 2019, (citată în continuare: „7 Dileme”).

4 P. LEgRAND, Comparația drepturilor pe înţelesul studenților mei, traducere și notă de A. MERCESCU și R. BERCEA, p. 176-210 în 7 Dileme. 
încerce, cu focalizări de cercetare pe adevărul rezultat din comparație, dar și cu un accent pe discursul referențial sau ficțional pe care dreptul comparat lar forma.

Fiecare text e probă de cunoaștere şi bună scriitură, care trădează formația filologică a autorului, dar și dorința sa de a nu cădea prizonier relaxat al locurilor comune. Autenticitatea şi dedicarea sunt fireşti, căutate fiind logicile și soluțiile pe care ar trebui dreptul comparat să nu le ignore. Avem un îndreptar de teme și rezolvări, pe care orice pasionat de drept prin comparație ar trebui să-l parcurgă. Sunt analizeze și interogații, pe care le putem nota - entuziaști ori critici, după știință şi umori, căci nu suntem identici, ci diverşi -, precum şi câteva soluții de jure, bune de notat şi aprofundat. Indiferent de preferințe, orientări sau idiosincrazii, este reconfortant să recunoști că 7 Dileme e o colecție valoroasă de căutări și propuneri intelectuale ce merită întregul efort al lectorului înspre cinstea autorului. Dintre temele abordate, ne permitem aici doar câteva sublinieri de amănunt, pentru a marca astfel sagacitatea şi gustul autorului pentru probleme cu adevărat dificile, dacă nu chiar pentru aporii; în rest, cartea trebuie citită toată.

La ce ar fi bun dreptul comparat? Ne ajută să descoperim, să selectăm și să reciclăm adevărul juridic. Poate din comparația de texte s-ar putea ivi cea mai bună soluție juridică din cele mai bune, căci textele vin din lumi culturale (juridice) distincte, dacă nu chiar de la antipozi intelectuali (e.g. common law vs. drept civil). Simple iluzii, suntem avertizați! Nu aflarea adevărului e miza și țelul comparației în drept. Texte fiind de comparat, interpretarea acestora nu este un zălog al depistării adevărului. Cheia de vizitare a textelor nu e decât relativă şi ține de hermeneutica personală a celui ce citește, trezește textul. 
„Nu există un adevăr al textului5.” De ce? Simplu, pentru că „grila prin care comparatistul va analiza acest text lipsit a priori de adevăr variază, inevitabil, în funcție de comparatist, căci nu există interpretare în care interpretul să se lanseze fără un bagaj conceptual prealabil6." Plus, prin comparație se produce cel de-al treilea text, cel care aparține interpretului, ce încearcă să înțeleagă, să explice și să înfățișeze rosturile celor două texte-de-drept venite din zări juridice diferite. Numai că și acest text terțiar - discursul interpretativ ori cheia hermeneutică a textului-de-drept - nu ar fi mai adevărat decât obiectul său, ci o „speculație interpretativă ${ }^{\prime \prime}$, care și ea reprimă adevărul. „Nu există <deci> o experiență a adevărului care să nu fie interpretativă"8. Evident, „adevărul textului depinde, într-o măsură esențială, nu doar de interpret, ci şi de convenții aflate dincolo de text"”. Contextul ar fi însă un supliment indispensabil - instrumental şi semantic. Aparté: ceea ce e în afara textului aparține contextului; iată un impediment dirimant pentru ca doar interpretarea să creeze singularități de-drept, aşa cum ar susține maître LEGRAND. Ignorăm aici orice plasare dincolo ori dincoace de text, căci realitatea celor 7 Dileme e textul - cel re-produs de comparatist, dar şi cel originar (produs de legiuitor), ambele discursuri fiind prinse în trama culturală (intertextuală). „Dreptul este, astfel, o expresie a culturii, experiența juridică a unei comunități fiind imersată într-un context cultural, astfel că, pentru comparatist, nu există nimic care să poată fi identificat ca esență a

\footnotetext{
57 Dileme, p. 23.

${ }^{6} 7$ Dileme, p. 22.

7 Dileme, p. 25 .

8 Ibidem.

${ }^{9}$ Ibidem. Sublinierile marcate cu cursiv aparțin - în toate preluările - autorului citat.
} 
juridicului, după cum, corelativ, nu există nimic care să fie, în mod esențial, înafara dreptului ${ }^{10}$."

De fapt, textul-despre-drept ar cuprinde mai multe adevăruri, iar interpretarea - oricât de pură s-ar pretinde - ar fi inaptă „să redea dreptul străin aşa cum este el, independent de orice amestec al interpretului ${ }^{11 "}$. Multitudinea de adevăruri face însă sumă nulă. Câsștigul s-ar afla deci altundeva, nu în adunare, ci în etalarea „particularităților locale ${ }^{12}$ ” dreptului naţional al interpretului, în „hermeneutica menită să confere sens ${ }^{13}$ ”. Da, nu ar fi exclus să existe sens fără adevăr, căci interpretarea comparatistă nu e referențială, ci ficțională. [Teza trebuie reținută, ea fiind proprie autorului recenzat.] Noima s-ar ascunde în scriitură, în textul-despre-drept. Acesta ar fi carnea interpretării; suflul hermeneuticii ce ar putea nutri (inclusiv) nomothetul, în efortul său herculean de a investi (textual) cu un adevărat sens normele, poruncile, învățăturile sale.

Cu textul pe text călcând, comparatistul va simți ce ar fi de făcut, din moment ce s-a produs atâta text. O sintaxă - plină de semne cuprinse într-un discurs, ce face compararea posibilă de drept. O sintaxă lipsită însă de o semantică autonomă şi impersonală. $\mathrm{O}$ astfel de situație ar fi specifică mai de grabă aritmeticii, care ne-a obişnuit cu semne și raporturi între acestea, lipsită fiind totuşi de vreo semantică ataşată. Sensul ar veni din afară, dinspre interpret şi din metatextul său. Textul-despre-drept este cel care învestește cu sensuri textul-de-drept; iată o concluzie care disipează orice dilemă. Aici, îndrăznim să sugerăm că dreptul - știința sa - nu ar părea nici consistent, nici

\footnotetext{
${ }^{10} 7$ Dileme, p. 141.

${ }^{11} 7$ Dileme, p. 27.

127 Dileme, p. 30.

13 Ibidem.
} 
complet - dacă ar fi să împrumutăm termenii lui Gödel. Incompletitudinii juridice i-ar veni însă de hac hermeneutica comparatistului prin propunerea de sensuri multiple, toate posibile în același sistem de referință, în funcție de aptitudinile și subiectivitatea analistului.

Învățătura (paradoxală, am spune) de memorat ar fi că efortul comparatistului servește dreptul intern dezvelindu-i sensurile, uneori ascunse chiar privirii legiuitorului. Dincolo de adevăr stă sensul; iată o axiomă, iar nu o dilemă, desprinsă din cele 7 Dileme. Nu plonjăm în plasa demonstrării axiomei, ci o livrăm. Prea abstractă să seducă spiritele practice, axioma ne marchează calea către rezervația de unicorni (metatextuali). Da, de aceea avem nevoie de Doamne, à son seul désir...

„Realitate înseamnă adevăr ${ }^{14}$.” Odată dispărut adevărul (prin multiplicare), pare mai la îndemână să sesizăm realitatea. Ignorăm parafraza hegeliană, ne captivează acum natura textelor de interpretare produse de comparatist; textul-despre-drept e unul strict comparatist aici. Totuși, pentru nu a sădi confuzie, trebuie amintit ce înseamnă realitatea pentru autor, la ce (fel de) realitate se raportează acesta. Se „are în vedere nu realitatea în sens de lume reală, ci realitatea sau lumea juridică $\breve{1}^{15}$." Distincţia tranşantă e inspirată de observația banală că „uneori, reglementările juridice par să recunoască și să concilieze (deci, să conserve) ele însele acest clivaj între fapt (adică realitatea propriu-zisă) și drept (adică realitatea juridică) ${ }^{16}$.” Stabilirea unor raporturi cu realitatea, dar și înțelegerea acesteia, dă întotdeauna bătăi de cap, dar poziția autorului trebuie acceptată dacă se vrea înțelegerea concepției sale despre interpretare şi discursul comparatist. Există, deci,

\footnotetext{
147 Dileme, p. 38.

15 Ibidem.

${ }^{16}$ Ibidem.
} 
realități (de non-fapt), care sunt textuale. Aici trimitem direct la teza autorului care include discursul comparatist printre cele ficționale, abandonând valențele referențiale ale acestuia. Poziția autorului nu este chiar de dată recentă. Acesta rămâne consecvent în a trata discursul despre-drept ca unul care se folosește de pre-textul referențial (textul-de-drept), pentru a decola apoi rapid, generând texte fiduciar-ficţionale. Toate acestea ne obligă și pe noi să reluăm succint câteva dintre ideile care probează pentru autor natura ficțională a dreptului comparat.

Astfel „interpretarea este, inițial, stimulată de ficţiune și se conduce, în bună măsură, după regulile acesteia ${ }^{17 .}$ ”Vom defini, deci, textul comparațiilor care se pot face în drept așa cum Gérard Genette a descris discursul zis de ficțiune: un <amalgam mai mult sau mai puține omogenizat de elemente eteroclite împrumutate în cea mai mare parte din realitate $>18$."Acest lucru ar fi de admis căci textele nu pot reproduce decât infidel, secvențial și imaginar realitatea de-drept, referentul. Desprinderea de textul de referință, abolirea referențialității, este o consecință a textualismului intrinsec dreptului comparat: un text-despre care nu fotografiază decât mișcat-umbrit o realitatea uneori improbabilă. Incertitudinea nu e consecința interogației, ci chiar substanța textuală a realității, când aceasta se identifică cu textul-de-lege. Ar exista un surplus enorm (discursiv) de identificare a dreptului cu „producțiile sale textuale ${ }^{19}$ ”. Inventariem deci o abundență de eforturi discursive căreia îi scapă totuși dreptul aplicat. Doar cel din urmă caracterizează dreptul ce ar merita să fie recunoscut ca viu, preferabil oricărui text-de-drept. Oricum, există drept și înafara acestor producții discursive și

\footnotetext{
${ }^{17} 7$ Dileme, p. 59.

${ }^{18}$ Ibidem.

${ }^{19} 7$ Dileme, p. 57.
} 
că, ceea ce se află dincolo de texte ar merita mai multă atenție (și implicit mai multe texte-despre). Prin urmare, ar trebui deschisă o discuție despre „suprapunerea perfectă pe care juriştii pozitiviști (în general, şi nu doar comparatiștii) o instaurează - ficțional, în oricare dintre sensuri - între drept şi normă în sens strict ${ }^{20}$.” Realitatea dreptului ar deveni mai efectivă prin dreptul aplicat-practicat, iar nu atât prin textele-de-drept însele. Se dă astfel semnalul marii evadări din discurs. O evaziune promisă din text către relațiile sociale amenajate de jurie, o scăpare în buclă, care ar îngădui ficțiunea interpretativă, cu fixarea mai precisă a ceea ce ar fi (de/în fapt) dreptul. Deci, „orice comparație a drepturilor este o ficțiune ${ }^{21}$."

Ni se indică astfel două căi ale dreptului de urmat simultan - una textuală, alta contextuală. Discursul comparatist este legătura explicativă, decodorul dreptului aplicat, căci el valorifică dinamic și concomitent cele două tipuri de texte - unele de reper-ință (de-drept), celelalte ficționale (despre-drept). Asistăm la lumea-ca-text, ca hipertext, în care realitatea e discursivă şi se identifică cu adevărul textual interşanjabil al diferitelor superdiscursuri. Sagace și sângeroasă abordare! Puterea textului devine astfel atotcuprinzătoare, metadiscursul fiind un exerciţiu eficace de suveranitate și servitute.

Raluca BERCEA este un autor matur și interesant. El trebuie citit, chiar dacă nu ai răsfoit niciodată defuncta Tel quel ori ești încă adormit, nu woke.

\footnotetext{
${ }^{20} 7$ Dileme, p. 58 .

${ }^{21} 7$ Dileme, p. 56.
} 